\title{
Desulfurispirillum indicum sp. nov., a selenate- and selenite-respiring bacterium isolated from an estuarine canal
}

\author{
Correspondence \\ Max M. Häggblom \\ haggblom@AESOP.Rutgers.edu
}

\author{
Ines Rauschenbach, ${ }^{1}$ Priya Narasingarao ${ }^{2}$ and Max M. Häggblom ${ }^{1}$ \\ ${ }^{1}$ Rutgers University, Department of Biochemistry and Microbiology, School of Environmental and
Biological Sciences, 76 Lipman Drive, New Brunswick, NJ 08901, USA \\ ${ }^{2}$ Marine Biology Research Division, Scripps Institution of Oceanography, University of California at \\ San Diego, La Jolla, CA 92093, USA
}

Selenium (Se), a naturally occurring element, is essential for most organisms (Conde \& Sanz Alaejos, 1997; Zannoni et al., 2007). Although considered to be a trace element, its toxicity is highly dependent on its oxidation state and speciation. Se occurs in a variety of oxidation states, water-soluble selenate $\left(\mathrm{SeO}_{4}{ }^{2-}\right)$ and selenite $\left(\mathrm{SeO}_{3}{ }^{2-}\right)$, insoluble elemental selenium $\left(\mathrm{Se}^{0}\right)$ and gaseous selenide. Even though redox transformations of selenium oxyanions can occur abiotically (Myneni et al., 1997; Kessi \& Hanselmann, 2004), the global selenium cycle is greatly influenced by micro-organisms (Stolz et al., 2006). Various microbial species have been found to not only reduce selenate and/or selenite to elemental Se, but to also respire selenate oxyanions in order to gain cellular energy (Oremland et al., 1989; Steinberg \& Oremland, 1990; Narasingarao \& Häggblom, 2007b; Stolz \& Oremland, 1999; Stolz et al., 2006). These selenium oxyanion-respiring micro-organisms display a broad phylogenetic diversity and can be found among the phyla 'Proteobacteria', 'Deferribacteres', 'Firmicutes' and 'Actinobacteria' (Narasingarao \& Häggblom, 2006, 2007a, b; Switzer Blum et al., 2001; von Wintzingerode et al., 2001). The ability of bacteria to use selenate and selenite and other alternative terminal electron acceptors, such arsenate,

The GenBank/EMBL/DDBJ accession number for the 16S rRNA gene sequence of strain $\mathrm{S}^{\top}{ }^{\top}$ is DQ991965. nitrate, sulfate and/or iron, plays a major role in the oxidation of organic carbon in sediments and contributes to the biogeochemical cycling of these elements in nature. In this study, strain $\mathrm{S5}^{\mathrm{T}}$, a novel member of the family Chrysiogenetes, is described.

Strain $\mathrm{S5}^{\mathrm{T}}$ is a strictly anaerobic, dissimilatory selenate- and selenite-respiring bacterium isolated from an enrichment culture of sediments collected in an estuarine channel in Chepauk in Chennai, located in southern India (Narasingarao \& Häggblom, 2007a). Strain $S 5^{\mathrm{T}}$ was isolated after sequential transfers into fresh anaerobic medium with selenate as electron acceptor and pyruvate as carbon source and electron donor. Purity of the culture was verified by microscopic analysis and by terminal restriction fragment length polymorphism analysis as described by Fennell et al. (2004). Strain $\mathrm{S}^{\mathrm{T}}$ was maintained in an anaerobic minimal salts medium (Fennell et al., 2004) with $20 \mathrm{mM}$ pyruvate as the carbon source and $10 \mathrm{mM}$ selenate as the electron donor under a headspace of $\mathrm{N}_{2}$.

Genomic DNA was extracted by phenol/chloroform extraction as described by Kerkhof \& Ward (1993). The 16S rRNA gene was selectively amplified by PCR from the genomic DNA as described by Narasingarao \& Häggblom (2006). PCR products were sequenced by Genewiz Inc, South Plainfield, NJ, USA. Sequence data were compiled 
using Contig Express (Vector NTI Suite; Informax). The $16 \mathrm{~S}$ rRNA gene sequences of related micro-organisms were identified by a BLAST search (Altschul et al., 1997) and downloaded from GenBank. Phylogenetic and molecular evolutionary analyses of all sequences were conducted using MEGA4 (Tamura et al., 2007), which utilizes CLUSTAL $\mathrm{w}$ (Chenna et al., 2003) to align sequences. Neighbourjoining and maximum-parsimony phylogenetic trees with 1000 bootstrap replications were reconstructed using the program package MEGA4 with the maximum composite likelihood model for nucleotide substitutions. Comparative $16 \mathrm{~S}$ rRNA gene sequence analysis placed strain $\mathrm{S}^{\mathrm{T}}$ within the family Chrysiogenaceae, which, at the time of writing, has only two known members. Chrysiogenes arsenatis, the first species to be identified, was isolated for its ability to respire arsenate to arsenite coupled to oxidation of acetate and other short-chain organic acids (Macy et al., 1996). Desulfurispirillum alkaliphilum, the second organism, is capable of reducing elemental sulfur to sulfide and nitrate to ammonium (Sorokin et al., 2007). The type strain of $D$. alkaliphilum only shared $91 \% 16 \mathrm{~S}$ rRNA gene similarity with that of $C$. arsenatis and so it was placed in a new genus, Desulfurispirillum (Sorokin et al., 2007). The $16 \mathrm{~S}$ rRNA gene sequence of strain $\mathrm{S}^{\mathrm{T}}$ shared similarities of 94 and $98 \%$, respectively, with those of the type strains of $C$. arsenatis and $D$. alkaliphilum. Phylogenetic analysis with unambiguously aligned $16 \mathrm{~S}$ rRNA gene sequences of strain $\mathrm{S} 5^{\mathrm{T}}$ and other related strains (Fig. 1) indicated that strain $\mathrm{S}^{\mathrm{T}}$ belongs to the family Chrysiogenaceae and is most closely related to D. alkaliphilum and C. arsenatis. This was supported by high bootstrap values in both the neighbourjoining and maximum-parsimony analyses. All further physiological and molecular characterizations of strain $\mathrm{S5}^{\mathrm{T}}$ were made in comparison to the two above-named organisms.

Strain $\mathrm{S}^{\mathrm{T}}$ was grown with selenate $(10 \mathrm{mM})$ or nitrate $(10 \mathrm{mM})$ as electron acceptors and pyruvate $(20 \mathrm{mM})$ as carbon source to examine cell morphology via transmission electron microscopy (Narasingarao \& Häggblom, 2006) and phase-contrast microscopy. Strain $\mathrm{S}^{\mathrm{T}}$ was a Gram-negative, slender, spiral-shaped bacterium, approximately $2-7 \mu \mathrm{m}$ long and $0.10-0.15 \mu \mathrm{m}$ in diameter (Table
1, Fig. 2). Cells grown in the presence of selenate produced a bright red precipitate that accumulated in the bottom of the culture tube. The precipitate was further evaluated and confirmed as elemental selenium by X-ray absorption near edge structure analysis (XANES; Narasingarao \& Häggblom, 2007a). Strain $S 5^{\mathrm{T}}$ grew in both liquid medium and soft agar shake tubes. It did not form distinct colonies when grown anaerobically in soft agar $(0.4 \%$ Noble agar; Difco) shake tubes with $10 \mathrm{mM}$ selenate or $10 \mathrm{mM}$ selenite. The agar first turned completely red and then black over a period of 14 days as the selenium oxyanions were reduced to elemental selenium.

Rapid motility was observed by microscopy; therefore, a flagella stain was applied to visualize the presence of flagella (Kodaka et al., 1982). One drop of liquid culture of strain $\mathrm{S}^{\mathrm{T}}$ was applied to a clean glass slide and allowed to air dry completely. The flagella stain was then applied for $10 \mathrm{~min}$ before being washed off with deionized water. Bipolar flagella were observed that extended about $4-6 \mu \mathrm{m}$ at either end of the cell and allowed for rapid movement of strain $\mathrm{S}^{\mathrm{T}}$ (Fig. 2b).

A wide range of electron donors and acceptors were used to characterize the metabolic capabilities of strain $\mathrm{S}^{\mathrm{T}}$ (Table 1). Selenium oxyanions, nitrate and arsenate were analysed using ion chromatography (DX 120; Dionex) as described previously (Knight et al., 2002). The organic acids pyruvate, lactate and acetate were measured using HPLC (Shimadzu) equipped with a $\mathrm{C}_{18}$ column $(250 \times 4.6 \mathrm{~mm}$, $5 \mu \mathrm{m}$ particle size, Sphereclone; Phenomenex) as described by Narasingarao \& Häggblom (2007a). Three consecutive transfers with no growth were scored as negative for substrate utilization.

In addition to respiring selenate to elemental selenium with pyruvate as the carbon source, strain $S 5^{\mathrm{T}}$ also respired selenite, arsenate and nitrate (to ammonium). Pyruvate, acetate and lactate were its preferred carbon sources. Neither $C$. arsenatis nor $D$. alkaliphilum respired selenate and selenite and $D$. alkaliphilum did not respire arsenate (Table 1). In addition to pyruvate, lactate and acetate, both C. arsenatis and $D$. alkaliphilum were also able to use fumarate as a carbon source (Macy et al., 1996; Sorokin

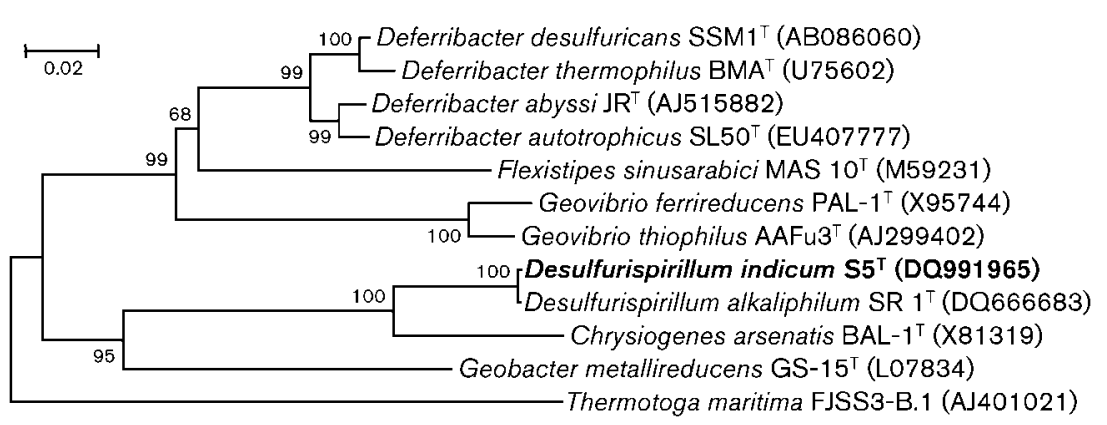

Fig. 1. Phylogenetic tree showing strain $S 5^{\top}$ with closely related strains. The tree was reconstructed with aligned 16S rRNA gene sequences using the neighbour-joining method with global gap removal algorithm. The evolutionary distances were computed using the maximum composite likelihood method (1251 positions in analysis). Bootstrap values above $50 \%$ are indicated. The $16 \mathrm{~S}$ rRNA gene sequence of Thermotoga maritima FJSS3-B.1 was used as outgroup. Bar, 0.02 substitutions per nucleotide position. 
Table 1. Differential physiological and metabolic characteristics of strain $S 5^{\top}$ and closely related species

Taxa: 1, strain $5^{\mathrm{T}} ; 2$, Desulfurispirillum alkaliphilum SR $1^{\mathrm{T}} ; 3$, Chrysiogenes arsenatis $\mathrm{BAL1}{ }^{\mathrm{T}}$ (data from Macy et al., 1996). All data are from this study, except where indicated. For strain $\mathrm{S}^{\mathrm{T}}$, electron acceptors were tested with $20 \mathrm{mM}$ pyruvate as electron donor and electron donors were tested with $10 \mathrm{mM}$ nitrate as electron acceptor. + , Positive; -, negative; ND, not determined. All strains tested were Gram-negative and strictly anaerobic. All tested positive for reduction of nitrate and oxidation of the short-chain organic acids acetate, lactate and pyruvate. All strains were negative for reduction of oxygen, chlorate, citrate and fumarate. All strains were negative for reduction of $\mathrm{Fe}^{3+}$, sulfate and $\mathrm{S}_{2} \mathrm{O}_{3}{ }^{2-} / \mathrm{SO}_{3}{ }^{2-}$ and oxidation of formate (data from Sorokin et al., 2007).

\begin{tabular}{|c|c|c|c|}
\hline Characteristics & 1 & 2 & 3 \\
\hline Morphology & Spirillum & Spirillum & Vibrio \\
\hline Motility & Highly motile & Highly motile & Motile \\
\hline \multicolumn{4}{|l|}{ Cell size $(\mu \mathrm{m})$ : } \\
\hline Length & $2-7$ & $2-5$ & $1-2$ \\
\hline Diameter & $0.10-0.15$ & $0.15-0.20$ & $0.50-0.75$ \\
\hline DNA G $+C$ content $(\mathrm{mol} \%)$ & 56.1 & $44.8 \pm 0.5^{*}$ & 49 \\
\hline Fermentation & - & + & - \\
\hline Optimum growth temperature $\left({ }^{\circ} \mathrm{C}\right)$ & 28 & 30 & $25-30$ \\
\hline \multicolumn{4}{|l|}{ Growth pH: } \\
\hline Range & $6.8-7.6$ & $8.0-10.0$ & $7.4-7.8$ \\
\hline Optimum & 7.4 & 9.0 & ND \\
\hline \multicolumn{4}{|l|}{$\mathrm{NaCl}$ concentration $(\mathrm{M})$ : } \\
\hline Range & $0.10-0.75$ & $0.1-2.5^{\star}$ & ND \\
\hline Optimum & 0.4 & 0.4 & $0.02 \dagger$ \\
\hline \multicolumn{4}{|l|}{ Electron donors: } \\
\hline Succinate & - & - & + \\
\hline Fumarate & - & + & + \\
\hline $\mathrm{HS}^{-}$ & - & $+^{*}$ & ND \\
\hline $\mathrm{H}_{2}$ & - & + & - \\
\hline Malate & - & - & + \\
\hline Propionate & - & + & ND \\
\hline \multicolumn{4}{|l|}{ Electron acceptors: } \\
\hline Arsenate & + & - & + \\
\hline Chromate & - & + & - \\
\hline DMSO & - & - & ND \\
\hline Nitrite & - & + & + \\
\hline Selenite & + & - & - \\
\hline Selenate & + & - & - \\
\hline Sulfur & - & + & - \\
\hline
\end{tabular}

${ }^{\star}$ Data from Sorokin et al. (2007).

$\dagger$ Calculated from Macy et al. (1989).

et al., 2007). In addition, D. alkaliphilum was also capable of using $\mathrm{HS}^{-}, \mathrm{H}_{2}$ and propionate as electron donors and carbon sources (Table 1) (Sorokin et al., 2007).

To determine optimum $\mathrm{pH}$, strain $\mathrm{S}^{\mathrm{T}}$ was grown with $10 \mathrm{mM}$ nitrate as electron acceptor and $20 \mathrm{mM}$ pyruvate as carbon source in anaerobic growth medium. The $\mathrm{pH}$ of the medium was adjusted with $\mathrm{HCl}$ and $\mathrm{NaOH}$ (pH 5-9). Strain $\mathrm{S}^{\mathrm{T}}$ grew at $\mathrm{pH}$ 6.8-7.6, with optimum growth at $\mathrm{pH} 7.4$, in contrast to $D$. alkaliphilum, which grew at $\mathrm{pH}$ 8.0-10.0 (Table 1). Growth of strain $\mathrm{S}^{\mathrm{T}}$ at different $\mathrm{NaCl}$ concentrations $(0-2.5 \mathrm{M})$ and temperatures (4$37^{\circ} \mathrm{C}$ ) was determined by growing cells in anaerobic medium ( $\mathrm{pH} 7.4$ ) with $10 \mathrm{mM}$ nitrate and $20 \mathrm{mM}$ pyruvate. The isolate grew between 20 and $37{ }^{\circ} \mathrm{C}$, with optimum growth at $28{ }^{\circ} \mathrm{C}$. It grew in $\mathrm{NaCl}$ concentrations of $0.10-0.75 \mathrm{M}$, with optimum growth at $0.40 \mathrm{M} \mathrm{NaCl}$.

The genomic DNA G+C content of strain $\mathrm{S}^{\mathrm{T}}$ was determined using a modified method of Mesbah et al. (1989). A Synergy 4U Fusion-RP 80A C18 reverse-phase column (Phenomenex) was used in an Agilent HPLC 1100 system. The mobile phase consisted of two eluents, $20 \mathrm{mM}$ ammonium acetate $(\mathrm{pH} 4.5$, eluent $\mathrm{A})$ and acetonitrile (eluent $\mathrm{B}$ ), at a flow rate of $1 \mathrm{ml} \mathrm{min}{ }^{-1}$. A gradient of eluent A from 95 to $60 \%$ was established over a period of 


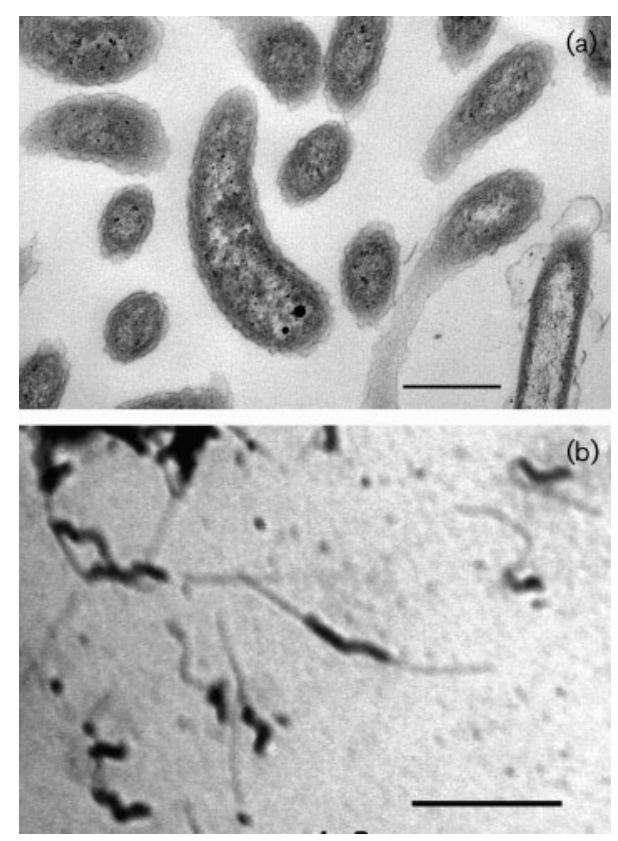

Fig. 2. Cell morphology of strain $\mathrm{S}^{\top}{ }^{\top}$. (a) Transmission electron micrographs of 2-week-old cultures with intracellular deposits of elemental selenium granules; bar, $0.5 \mu \mathrm{m}$. (b) Phase-contrast microphotograph of cells grown with nitrate $(10 \mathrm{mM})$ and pyruvate $(20 \mathrm{mM})$ and stained with flagella stain; bar, $5 \mu \mathrm{m}$.

$10 \mathrm{~min}$. Nucleosides were detected at a wavelength of $260 \mathrm{~nm}$. Salmon sperm DNA was used for calibration with Sedimenticola selenatireducens $\mathrm{AK} 4 \mathrm{OH} 1^{\mathrm{T}}$ as control. The $\mathrm{G}+\mathrm{C}$ content of strain $\mathrm{S}^{\mathrm{T}}$ was $56 \mathrm{~mol} \%$, which differed greatly from those of $C$. arsenatis $(49 \mathrm{~mol} \%)$ and $D$. alkaliphilum (44.8 $\mathrm{mol} \%$ ), thus supporting the classification of strain $\mathrm{S}^{\mathrm{T}}$ as a representative of a novel species of Desulfurispirillum (Table 1).

The fatty acid content of strain $\mathrm{S} 5^{\mathrm{T}}$ was analysed using cells grown at $28{ }^{\circ} \mathrm{C}$ with $20 \mathrm{mM}$ pyruvate and $10 \mathrm{mM}$ nitrate. D. alkaliphilum was grown at $28{ }^{\circ} \mathrm{C}$ with $20 \mathrm{mM}$ acetate as electron donor and $10 \mathrm{mM}$ nitrate as electron acceptor ( $\mathrm{pH} 9$ ). Cellular fatty acids were methylated and analysed as described previously (Narasingarao \& Häggblom, 2006) using an HP 5890 series II GC (Hewlett Packard) with the Sherlock Microbial Identification system (MIDI). The identities of fatty acid methyl esters detected by MIDI were further confirmed by GC-MS using an Agilent GC Series 6890 GC-MS. The two most common fatty acids found in strain $\mathrm{S}^{\mathrm{T}}$ were $\mathrm{C}_{18: 1} \omega 7 \mathrm{c}(38.5 \%)$ and $\mathrm{C}_{16: 0}$ $(20.6 \%)$. Overall, unsaturated fatty acids, such as $\mathrm{C}_{18: 1} \omega 7 c, \mathrm{C}_{16: 1} \omega 7 c$ and $\mathrm{C}_{16: 1} \omega 5 c$ made up about $56 \%$ of all fatty acids in strain $\mathrm{S}^{\mathrm{T}}$. The predominant straightchain saturated fatty acids were $\mathrm{C}_{12: 0}, \mathrm{C}_{16: 0}$ and $\mathrm{C}_{18: 0}$, which made up about $25 \%$ of all fatty acids (Table 2 ). Strain $\mathrm{S}^{\mathrm{T}}$ also contained 3-hydroxy fatty acids, mainly $\mathrm{C}_{12: 0} 3-\mathrm{OH}$ and $\mathrm{C}_{12: 1} 3-\mathrm{OH}$, which are indicative of fatty acids contained in the lipopolysaccharides of the outer
Table 2. Cellular fatty acid compositions (\%) of strain $\mathrm{S}^{\top}$ and Desulfurispirillum alkaliphilum SR $1^{\top}$

Strains: $1, S 5^{\mathrm{T}} ; 2$, Desulfurispirillum alkaliphilum $\mathrm{SR} 1^{\mathrm{T}}$. Strain $\mathrm{S} 5^{\mathrm{T}}$ was grown at $28{ }^{\circ} \mathrm{C}$ with $20 \mathrm{mM}$ pyruvate as electron donor and $10 \mathrm{mM}$ nitrate as electron acceptor. D. alkaliphilum was grown at $28{ }^{\circ} \mathrm{C}$ with $20 \mathrm{mM}$ acetate as electron donor and $10 \mathrm{mM}$ nitrate as electron acceptor. ND, Not detected.

\begin{tabular}{|lcc|}
\hline Fatty acid & $\mathbf{1}$ & $\mathbf{2}$ \\
\hline $\mathrm{C}_{12: 0}$ & $1.4 \pm 0.8$ & $3.2 \pm 0.3$ \\
$\mathrm{C}_{12: 1} 3-\mathrm{OH}$ & $4.1 \pm 1.8$ & $1.7 \pm 0.1$ \\
$\mathrm{C}_{12: 0} 3-\mathrm{OH}$ & $1.4 \pm 0.7$ & $0.4 \pm 0.1$ \\
$\mathrm{C}_{14: 0}$ & $\mathrm{ND}$ & $0.7 \pm 0.4$ \\
iso- $_{15: 0} 3-\mathrm{OH}$ & $0.5 \pm 0.7$ & $\mathrm{ND}$ \\
$\mathrm{C}_{15: 0} 2-\mathrm{OH}$ & $0.5 \pm 0.7$ & $\mathrm{ND}$ \\
$\mathrm{C}_{16: 1} \omega 9 c$ & $1.1 \pm 0.2$ & $1.3 \pm 0.2$ \\
$\mathrm{C}_{16: 1} \omega 7 c$ & $6.7 \pm 0.8$ & $4.8 \pm 0.4$ \\
$\mathrm{C}_{16: 1} \omega 5 c$ & $4.3 \pm 0.6$ & $3.5 \pm 0.2$ \\
$\mathrm{C}_{16: 0}$ & $20.6 \pm 3.6$ & $14.9 \pm 0.9$ \\
iso- $_{17: 1} \omega 5 c$ & $\mathrm{ND}$ & $8.9 \pm 0.6$ \\
$\mathrm{C}_{17: 1} \omega 8 c$ & $0.9 \pm 0.4$ & $\mathrm{ND}$ \\
$\mathrm{C}_{17: 1} \omega 6 c$ & $2.1 \pm 0.1$ & $1.4 \pm 0.2$ \\
iso- $_{17: 0} 3-\mathrm{OH}$ & $7.8 \pm 11$ & $\mathrm{ND}$ \\
$\mathrm{C}_{18: 1} \omega 9 c$ & $\mathrm{ND}$ & $0.6 \pm 0.1$ \\
$\mathrm{C}_{18: 1} \omega 7 c$ & $38.5 \pm 10.1$ & $39.6 \pm 3.3$ \\
$\mathrm{C}_{18: 1} \omega 5 c$ & $2.9 \pm 0.7$ & $2.1 \pm 0.3$ \\
$\mathrm{C}_{18: 0}$ & $3.2 \pm 1.5$ & $3.1 \pm 0.4$ \\
iso- $\mathrm{C}_{18: 1} \mathrm{H}$ & $1.0 \pm 0$ & $\mathrm{ND}$ \\
iso- $\mathrm{C}_{18: 1} \omega 8 c \mathrm{H}$ & $3.9 \pm 1.6$ & $\mathrm{ND}$ \\
& & \\
\hline & & \\
\hline
\end{tabular}

membranes of Gram-negative bacteria. A fair amount of iso- $\mathrm{C}_{17: 0} 3-\mathrm{OH}(7.8 \%)$ was also detected. In contrast, the fatty acid composition of its closest relative, D. alkaliphilum, grown under as identical conditions as possible, was distinctly different (Table 2). Overall, the fatty acid composition of strain $\mathrm{S}^{\mathrm{T}}$ was made up of $14.3 \%$ hydroxy fatty acids compared to only $2.1 \%$ detected in $D$. alkaliphilum. In strain $\mathrm{S}^{\mathrm{T}}$ and $D$. alkaliphilum, the most prevalent fatty acids were $\mathrm{C}_{18: 1} \omega 7 c$ and $\mathrm{C}_{16: 0}$; however, the abundance of $\mathrm{C}_{16: 0}$ differed ( $15 \%$ in $D$. alkaliphilum vs $21 \%$ in strain $\left.\mathrm{S}^{\mathrm{T}}\right)$. Straight-chain saturated fatty acids $\left(\mathrm{C}_{12: 0}, \mathrm{C}_{16: 0}, \mathrm{C}_{14: 0}\right.$ and $\left.\mathrm{C}_{18: 0}\right)$ made up $22 \%$ of all fatty acids. The fatty acid composition determined for $D$. alkaliphilum differed slightly from that reported previously by Sorokin et al. (2007), probably due to the different growth conditions.

\section{Description of Desulfurispirillum indicum sp. nov.}

Desulfurispirillum indicum (in'di.cum. L. neut. adj. indicum of India, Indian).

Gram-negative, highly motile, spiral-shaped bacterium, approximately $2-7 \mu \mathrm{m}$ long and $0.10-0.15 \mu \mathrm{m}$ in diameter. Strictly anaerobic. Non-fermenting. Respires selenate to elemental selenium coupled to utilization of short-chain organic acids. Capable of selenite, nitrate and arsenate respiration. Mesophilic, with a maximum growth temper- 
ature of $37{ }^{\circ} \mathrm{C}$ (optimum at $28{ }^{\circ} \mathrm{C}$ ). Tolerates $\mathrm{NaCl}$ concentrations of $0.10-0.75 \mathrm{M}$. The predominant cellular fatty acids are $\mathrm{C}_{12: 1} 3-\mathrm{OH}, \mathrm{C}_{16: 0}, \mathrm{C}_{16: 1} \omega 7 c$, iso- $\mathrm{C}_{17: 0} 3-\mathrm{OH}$ and $\mathrm{C}_{18: 1} \omega 7 c$. Groups within the family Chrysiogenaceae.

The type strain is $\mathrm{S}^{\mathrm{T}}\left(=\mathrm{DSM} 22839^{\mathrm{T}}=\mathrm{ATCC}\right.$ BAA$\left.1389^{\mathrm{T}}\right)$, isolated for its ability to respire selenate to elemental selenium from an estuarine canal in Chepauk in Chennai, located in southern India. The genomic DNA $\mathrm{G}+\mathrm{C}$ content of the type strain is $56 \mathrm{~mol} \%$.

\section{Acknowledgements}

We are grateful to Valentin Starovoytov for his help with the electron microscopy and to J. P. Euzéby for advice in nomenclature. We thank Dimitri Sorokin and Gerard Muyzer for providing a culture of Desulfurispirillum alkaliphilum. This study was supported in part by the New Jersey Water Resources Research Institute.

\section{References}

Altschul, S. F., Madden, T. L., Schäffer, A. A., Zhang, J., Zhang, Z., Miller, W. \& Lipman, D. J. (1997). Gapped BLAST and PSI-BLAST: a new generation of protein database search programs. Nucleic Acids Rees 25, 3389-3402.

Chenna, R., Sugawara, H., Koike, T., Lopez, R., Gibson, T. J., Higgins, D. G. \& Thompson, J. D. (2003). Multiple sequence alignment with the Clustal series of programs. Nucleic Acids Res 31, 3497-3500.

Conde, J. E. \& Sanz Alaejos, M. (1997). Selenium concentrations in natural and environmental waters. Chem Rev 97, 1979-2004.

Fennell, D. E., Rhee, S. K., Ahn, Y. B., Häggblom, M. M. \& Kerkhof, L. J. (2004). Detection and characterization of a dehalogenating microorganism by terminal restriction fragment length polymorphism fingerprinting of $16 \mathrm{~S}$ rRNA in a sulfidogenic, 2-bromophenolutilizing enrichment. Appl Environ Microbiol 70, 1169-1175.

Kerkhof, L. \& Ward, B. B. (1993). Comparison of nucleic acid hybridization and fluorometry for measurement of the relationship between RNA/DNA ratio and growth rate in a marine bacterium. Appl Environ Microbiol 59, 1303-1309.

Kessi, J. \& Hanselmann, K. W. (2004). Similarities between the abiotic reduction of selenite with glutathione and the dissimilatory reaction mediated by Rhodospirillum rubrum and Escherichia coli. J Biol Chem 279, 50662-50669.

Knight, V. K., Nijenhuis, I., Kerkhof, L. J. \& Häggblom, M. M. (2002). Degradation of aromatic compounds coupled to selenate reduction. Geomicrobiol J 19, 77-86.

Kodaka, H., Armfield, A. Y., Lombard, G. L. \& Dowell, V. R., Jr (1982). Practical procedure for demonstrating bacterial flagella. J Clin Microbiol 16, 948-952.

Macy, J. M., Michel, T. A. \& Kirsch, D. G. (1989). Selenate reduction by a Pseudomonas species: a new mode of anaerobic respiration. FEMS Microbiol Lett 52, 195-198.
Macy, J. M., Nunan, K., Hagen, K. D., Dixon, D. R., Harbour, P. J., Cahill, M. \& Sly, L. I. (1996). Chrysiogenes arsenatis gen. nov., sp. nov., a new arsenate-respiring bacterium isolated from gold mine wastewater. Int J Syst Bacteriol 46, 1153-1157.

Mesbah, M., Premachandran, U. \& Whitman, W. B. (1989). Precise measurement of the $\mathrm{G}+\mathrm{C}$ content of deoxyribonucleic acid by highperformance liquid chromatography. Int J Syst Bacteriol 39, 159-167.

Myneni, S. C. B., Tokunaga, T. K. \& Brown, G. E. (1997). Abiotic selenium redox transformations in the presence of $\mathrm{Fe}(\mathrm{II}, \mathrm{III})$ oxides. Science 278, 1106-1109.

Narasingarao, P. \& Häggblom, M. M. (2006). Sedimenticola selenatireducens, gen. nov., sp. nov., an anaerobic selenate-respiring bacterium isolated from estuarine sediment. Syst Appl Microbiol 29, 382-388.

Narasingarao, P. \& Häggblom, M. M. (2007a). Identification of anaerobic selenate-respiring bacteria from aquatic sediments. Appl Environ Microbiol 73, 3519-3527.

Narasingarao, P. \& Häggblom, M. M. (2007b). Pelobacter seleniigenes sp. nov., a selenate-respiring bacterium. Int J Syst Evol Microbiol 57, 1937-1942.

Oremland, R. S., Hollibaugh, J. T., Maest, A. S., Presser, T. S., Miller, L. G. \& Culbertson, C. W. (1989). Selenate reduction to elemental selenium by anaerobic bacteria in sediments and culture: biogeochemical significance of a novel, sulfate-independent respiration. Appl Environ Microbiol 55, 2333-2343.

Sorokin, D. Y., Foti, M., Tindall, B. J. \& Muyzer, G. (2007). Desulfurispirillum alkaliphilum gen. nov. sp. nov., a novel obligately anaerobic sulfur- and dissimilatory nitrate-reducing bacterium from a full-scale sulfide-removing bioreactor. Extremophiles 11, 363-370.

Steinberg, N. A. \& Oremland, R. S. (1990). Dissimilatory selenate reduction potentials in a diversity of sediment types. Appl Environ Microbiol 56, 3550-3557.

Stolz, J. F. \& Oremland, R. S. (1999). Bacterial respiration of arsenic and selenium. FEMS Microbiol Rev 23, 615-627.

Stolz, J. F., Basu, P., Santini, J. M. \& Oremland, R. S. (2006). Arsenic and selenium in microbial metabolism. Annu Rev Microbiol 60, 107130.

Switzer Blum, J., Stolz, J. F., Oren, A. \& Oremland, R. S. (2001). Selenihalanaerobacter shriftii gen. nov., sp. nov., a halophilic anaerobe from Dead Sea sediments that respires selenate. Arch Microbiol 175, 208-219.

Tamura, K., Dudley, J., Nei, M. \& Kumar, S. (2007). MEGA4: molecular evolutionary genetics analysis (MEGA) software version 4.0. Mol Biol Evol 24, 1596-1599.

von Wintzingerode, F., Göbel, U. B., Siddiqui, R. A., Rösick, U., Schumann, P., Frühling, A., Rohde, M., Pukall, R. \& Stackebrandt, E. (2001). Salana multivorans gen. nov., sp. nov., a novel actinobacterium isolated from an anaerobic bioreactor and capable of selenate reduction. Int J Syst Evol Microbiol 51, 1653-1661.

Zannoni, D., Borsetti, F., Harrison, J. J. \& Turner, R. J. (2007). The bacterial response to the chalcogen metalloids Se and Te. Adv Microb Physiol 53, 1-72. 